\title{
Experimental Study of Drying Characteristics and Mathematical Modeling for Air Drying of Germinated Brown Rice
}

(Kajian Eksperimen Ciri Pengeringan dan Model Matematik untuk Pengeringan Udara Beras Perang)

\author{
ZHENWEI Yu, KHURRAM YousAF, YU WANG \& KUNJIE CHEN*
}

\begin{abstract}
In view of existing problems in the drying process of germinated brown rice (GBR), the self-made hot air drying test system was utilized. The drying medium temperature and wind speed were selected as the drying parameters, and different constraints were set for the test. The effects of the drying medium temperature and wind speed on the drying rate and unit energy consumption were examined, and the drying mathematical models of GBR were established. The results perceived that as the temperature rose, and the wind speed increased, the drying rate increased accordingly. When the temperature was above $95^{\circ} \mathrm{C}$, wind speed exceeded $3.6 \mathrm{~m} / \mathrm{s}$; the drying rate would not change deliberately. When the temperature of the drying medium rose, the change rate during the drying preheating stage and the deceleration stage increased sharply, whereas the drying rate in the constant-speed drying stage increased, and the drying time was greatly shortened. Unit energy consumption decreased with the increase of temperature and increased with increasing wind speed. Furthermore, when the drying temperature was ranged between $50^{\circ} \mathrm{C}$ and $80^{\circ} \mathrm{C}$, the unit energy consumption changed meaningfully; when the medium temperature was between $80^{\circ} \mathrm{C}$ and $110^{\circ} \mathrm{C}$, the unit heat consumption turned slowly. Wang and Singh's model could best simulate the drying process of GBR within the experimental settings. And then comparing the RMSE and under the various dry conditions, the data of Wang and Singh model were between $1.6 \%-2.8 \%$ and $2.5 \times 10-4-5 \times 10-4$. The $R^{2}$ values of the model were higher than 0.98 .
\end{abstract}

Keywords: Drying characteristics; energy consumption; germinated brown rice; mathematical model; moisture content

\section{ABSTRAK}

Disebabkan masalah sedia ada dalam proses pengeringan percambahan beras perang (GBR), sistem ujian pengeringan udara panas buatan sendiri telah digunakan. Pengeringan suhu sederhana dan kelajuan angin dipilih sebagai parameter pengeringan dan kekangan berbeza ditetapkan untuk ujian. Kesan daripada pengeringan suhu sederhana dan kelajuan angin pada kadar pengeringan dan penggunaan tenaga unit disemak dan pengeringan model matematik GBR telah ditubuhkan. Keputusan menunjukkan apabila suhu meningkat dan kelajuan angin bertambah, kadar pengeringan meningkat dengan sewajarnya. Apabila suhu melebihi $95^{\circ} \mathrm{C}$, kelajuan angin melebihi $3.6 \mathrm{~m} / \mathrm{s}$; kadar pengeringan tidak akan berubah secara terancang. Apabila suhu pengeringan itu meningkat, kadar perubahan pada peringkat pra-pemanasan pengeringan dan peringkat nyahpecutan meningkat secara mendadak, sedangkan kadar pengeringan pada peringkat pengeringan laju meningkat dan masa pengeringan telah banyak dipendekkan. Penggunaan tenaga unit menurun dengan peningkatan suhu dan meningkat dengan kelajuan angin. Tambahan pula, apabila suhu pengeringan berada dalam lingkungan $50^{\circ} \mathrm{C}$ hingga $80^{\circ} \mathrm{C}$, penggunaan tenaga unit juga turut berubah; apabila suhu sederhana adalah antara $80^{\circ} \mathrm{C}$ dan $110^{\circ} \mathrm{C}$, penggunaan haba unit bertukar menjadi perlahan. Model Wang dan Singh adalah stimulasi terbaik bagi proses pengeringan GBR dalam tetapan uji kaji. Apabila perbandingan RMSE dijalankan pada pelbagai keadaan pengeringan, data bagi model Wang dan Singh adalah antara 1.6\%-2.8\% dan 2.5 × 10-4-5 × 10-4. Nilai model $R^{2}$ ini lebih tinggi daripada 0.98 .

Kata kunci: Ciri pengeringan; kandungan lembapan; model matematik; penggunaan tenaga; percambahan beras perang

\section{INTRODUCTION}

Rice is one of the main cereals produced in the world and the primary staple food for almost half of the population worldwide. It has been assumed a positive link between white rice intake and risk factors of cardiovascular diseases, including metabolic syndrome and type 2 diabetes in low and middle-income countries (Ranmeechai \& Photchanachai 2017). In recent years, much attention has been paid on the health benefits of brown rice (BR). BR contains health promoting compounds, including dietary fiber, $\gamma$-aminobutyric acid (GABA), vitamins, phenolic compounds, and $\gamma$-oryzanol that are mainly located in the germ and bran layers, which are removed during rice polishing and milling (Liu et al. 2018, 2016).

Germinated brown rice (GBR), a kind of brown rice product, is made up of young buds and endosperm with bran layer obtained by germinating brown rice to a certain bud length (Hao et al. 2019; Li et al. 2018, 2017). That is 
to say, brown rice is cultured at a certain temperature and humidity, and then dried when it germinates to a certain degree. The essence of brown rice germination is to activate and release the enzymes contained in brown rice, and meanwhile, the rich nutrients such as vitamins, minerals, and dietary fiber are retained (Lee et al. 2019). Therefore, compared with brown rice and white rice, GBR has more nutritional value (Bordiga et al. 2014; Shen et al. 2019). The emergence of GBR has greatly enriched rice products, and significantly increased the additional value of rice as well as has a comprehensive prospect for development.

According to the drying characteristics and related literature of GBR, the initial moisture content of GBR is relatively high (Cáceres et al. 2017). Therefore, conventional constant temperature drying methods should be used. If lower drying temperature were adopted, the economy of the drying process would be unsatisfactory due to long drying time, low drying efficiency, and increased energy consumption. If higher drying temperature is adopted, the temperature of the material will be too high in the later drying period, which will adversely affect the drying quality (Caceres et al. 2014; Chungcharoen et al. 2014; Yousaf et al. 2018). Therefore, it is necessary to design a drying process suitable for its material characteristics to solve the drying problem of GBR.

In the production of GBR, the drying process consumes the most energy in the whole production process and has a direct impact on the quality of GBR (Yodpitak et al. 2019). There have been a large number of domestic studies on the drying characteristics of rice, rapeseed, fruit, and vegetables, some of which have been successfully applied and achieved significant economic benefits; nevertheless, there is no research about the GBR. In order to reduce the production cost of GBR as well as ensure its quality, the drying characteristics of GBR must be studied, which could provide the scientific theoretical basis for the development and promotion of GBR and its products. Therefore, in this study, the drying characteristics of GBR were studied. Meanwhile, the effects of drying medium temperature and wind speed on drying rate and unit energy consumption were analyzed.

\section{MATERIALS AND METHODS}

\section{EXPERIMENTAL MATERIALS AND DEVICES}

Late Japonica rice 'south stem 44', dried to standard moisture, was used as raw material. Before the experiment, the husking machine was used to remove the husk and obtain unpolished rice with a moisture content of $14.6 \%$. The brown rice needed to be cleaned and sterilized before soaking. The experimental water tank was filled with distilled water and connected to the ozone circulation treatment system. Most of the microorganisms in the water could be killed by ozone for $20 \mathrm{~min}$, and then allowed to stand after sterilization. The brown rice was added to the water tank, and the temperature of the water $\left(25^{\circ} \mathrm{C}\right)$ was strictly controlled during the soaking, so that the brown rice was fully absorbed. To keep the soaking water clean and hygienic, the water should be changed once after being used for $12 \mathrm{~h}$. After the soaking process was finished, the water-absorbed brown rice was evenly spread in a constant temperature and humidity incubator, and the germination temperature was adjusted to $30^{\circ} \mathrm{C}$. The germination would be terminated when the bud length of the brown rice ranged from 0.5 to $1 \mathrm{~mm}$. The enzyme was inactivated by using hot water at $80^{\circ} \mathrm{C}$ for $10 \mathrm{~min}$. After the inactivating enzyme treatment, it should be quickly cooled and stored in a plastic package to prepare for the next drying experiment.

The hot air drying device was used, which is mainly composed of an electric heater, drying chamber, the main circulation fan, corresponding sensor, and data acquisition system. The sensor detected the temperature, humidity, wind speed, and other drying parameters of the drying medium. In order to measure the drying rate curve of the material, the real-time information of the material, and the drying medium during the drying process were collected through the self-designed data acquisition device, shown in Figure 1.

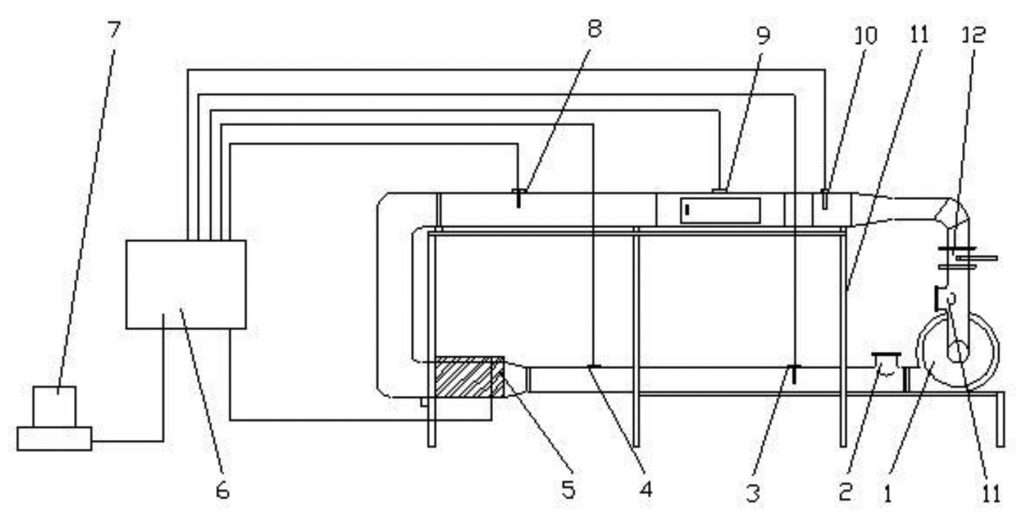

FIGURE 1. Schematic diagram of the hot air drying device

1 fan 2 . intake valve 3 . temperature and humidity sensor 4 . wind speed transducer 5 . electric heater 6 . data collector 7. IPC 8. temperature and humidity sensor 9 . weight sensor 10 . wind speed transducer 11 . shelf 12 . vent valve 


\section{METHODS}

Prepared GBR was placed in a drying net. All instruments in the experiment set up were checked. The fan was opened, then adjusting the valve to the predetermined wind speed. Turn on the heater to preheat the air, and the test can be started after the air temperature reached and stabilized at the preset temperature. The heater was turned on to preheat the air, and the test was not started until the air temperature reached and stabilized at the preset temperature. The drying door was opened, and the homemade GBR (approximately $150 \mathrm{~g}$ ) was put into the pallet. Then, after closing the drying door, the sensor data were recorded with the computer software. Each sensor was observed at any time in order to check whether it was stable in the present value and whether each sensor was in the range of the working range. If the working environment exceeded the normal range of the sensor, it should be adjusted in time. The experiment would be ended when the wet-basis moisture content of the material was close to $14 \%$ by observing the data of the weight sensor. At the end of the experiment, the electric heater was turned off, and then the fan was stopped before taking out the sample.

\section{TEST DATA AND INDICATORS}

Direct Test Data Environmental temperature, environmental humidity, the temperature of drying medium, the humidity of drying medium, temperature, and humidity of the medium after drying, the weight of GBR, drying time, wind speed of drying medium.

Wet-Base Moisture Content $M_{s}$ Wet-base moisture content $\left(M_{S}\right)$ is the percentage of moisture content in grain by weight.

$$
M_{S}=\frac{W}{G} \times 100 \%
$$

where $G$ is grain weight, $\mathrm{kg}$; and $W$ is the weight of moisture in grain, $\mathrm{kg}$.

Dry-Base Moisture Content $M_{g}$ Dry-base moisture content $\left(M_{g}\right)$ is defined as the percentage of moisture weight in a grain relative to its absolute dry weight.

$$
M_{g}=\frac{W}{G_{g}} \times 100 \%
$$

where $G_{g}$ is the weight of an absolute dry matter in grain, $\mathrm{kg}$.

The Amount of Water Removed Per Hour

$$
W=\frac{G\left(M_{C}-M_{Z}\right)}{\left(1-M_{Z}\right)}
$$

where $W$ is the amount of water removed per hour, $\mathrm{kg} / \mathrm{h}$; $G$ is the weight of wet material, $\mathrm{kg} ; M_{C}$ is initial moisture content of experimental materials (Wet-base) percentage; $M_{Z}$ is final moisture content of experimental materials (Wet-base) percentage; and $T$ is drying time in $\mathrm{h}$.

\section{The Removal Rate of Water Per Hour}

$$
P=\frac{\left(M_{C}-M_{Z}\right)}{T}
$$

\section{Unit Energy Consumption}

$$
\Delta q=\frac{U I t+P t}{W}
$$

where $U$ is the operating voltage of electric heater, $\mathrm{V} ; I$ is operating current of electric heater, A; $T$ is drying time, h; and $P$ is the power of the fan, $\mathrm{kW}$.

Drying Model The material drying process is a complex heat and mass transfer process. During drying, heat and mass transfer between the kernel and its environment occur simultaneously. This involved transfer phenomenon results in certain difficulty to determine the drying parameters (Argo et al. 2018; Canabarro et al. 2019). To simplify this complicated procedure, a lumped parameter model (thin-layer model) technique is usually used. The lumped parameter model assumes that there is no temperature gradient inside the dried kernel, and the temperature is the ambient temperature supplied by the drying air. This assumption causes an error at the beginning of the drying process, and this error might be lessened to an acceptable level when the thickness of the product is reduced to about one thickness of the grain kernel. Extensive researches have been conducted to simulate this lumped process (Idlimam et al. 2016; Vijayan et al. 2016), and more than a hundred articles on the mathematical modeling of thin-layer drying have been published in the last decades. Several commonly used empirical and semi-empirical drying mathematical models are summarized to describe the drying rule of materials quantitatively (Aykin-Dincer \& Erbas 2018; Mujaffar \& Sankat 2015). The common thin layer drying models used to describe agricultural materials are shown in Table 1.

In the model equation, $M R$ is the moisture ratio, which is used to indicate how much moisture remains in the material under certain drying conditions (Jian \& Jayas 2018; Sahin \& Ozturk 2016). The calculation formula is shown in (6).

$$
M R=\frac{M-M_{e}}{M o-M_{e}}
$$

where $M$ is dry-base moisture content of the material at a particular time, $\% ; M_{e}$ is dry base moisture content after material balance, $\%$; and $M_{o}$ is initial dry-base moisture content of material, \%. However, $M R$ is simplified to $M /$ 
TABLE 1. Mathematical models for drying

\begin{tabular}{ccc}
\hline Instance & Model name & Model equation \\
\hline 1 & Newton & $M R=\exp (-k t)$ \\
2 & Page & $M R=\exp \left(-k t^{n}\right)$ \\
3 & Henderson and Pabis & $M R=a \exp (-k t)$ \\
4 & Two term & $M R=a \exp (-k t)+b \exp (-g t)$ \\
5 & Wang and Singh & $M R=1+a t+b t^{2}$ \\
\hline
\end{tabular}

$M_{0}$, because $M g$ is very small compared to $M$ and $M_{0}(\mathrm{El}$ Khadraoui et al. 2019; Lakshmi et al. 2018).

The regression analysis was performed using the MATLAB Program. The correlation coefficient $\left(\mathrm{R}^{2}\right)$, reduced squared-chi $\left(\chi^{2}\right)$ and the root mean square error (RMSE) were used as criteria for adequacy of the fit (Chandra Mohan \& Talukdar 2010; Lee \& Zuo 2013; Leite et al. 2018). The higher R-values and the lower $\chi^{2}$ and RMSE values indicate the better goodness of fit. Root-mean-square error (RMSE) and Chi-square $\chi^{2}$ are defined as follows:

$$
R M S E=\sqrt{\frac{\sum_{i=1}^{N}\left(M R_{p r e, i}-M R_{\text {exp }, i}\right)^{2}}{N}}
$$

$$
\chi^{2}=\frac{\sum_{i=1}^{N}\left(M R_{\exp , i}-M R_{p r e, i}\right)^{2}}{N-n}
$$

where $M R_{\text {pre, } \mathrm{I}}$ is predicted moisture ratio; $M R_{\text {exp,I }}$ is the experimental value of water ratio; $N$ is observation frequency; and $n$ is the number of constant terms in a regression model.

\section{RESULTS AND DISCUSSION}

\section{INFLUENCE OF MEDIUM WIND SPEED AND TEMPERATURE ON DRYING CURVE}

It can be seen from Figure 2, as the temperature rose, the drying rate increased and the drying time decreased, which meant that increasing the temperature could enhance the drying capacity of the drying medium. However, too high, the temperature of the drying medium had a particular effect on the quality and active ingredient of the dry material. Nevertheless, when the temperature rose to $95^{\circ} \mathrm{C}$, the increasing temperature had no significant impact on the drying rate.

Figure 3 shows that as the wind speed of the medium increased, the drying time of the GBR was shortened, and drying rate was accelerated, which means increasing wind speed of the medium could improve the drying capacity of the drying medium, as well. However, when the wind speed rose to $3.2 \mathrm{~m} / \mathrm{s}$, increasing the wind speed of the medium had no significant influence on the drying rate.

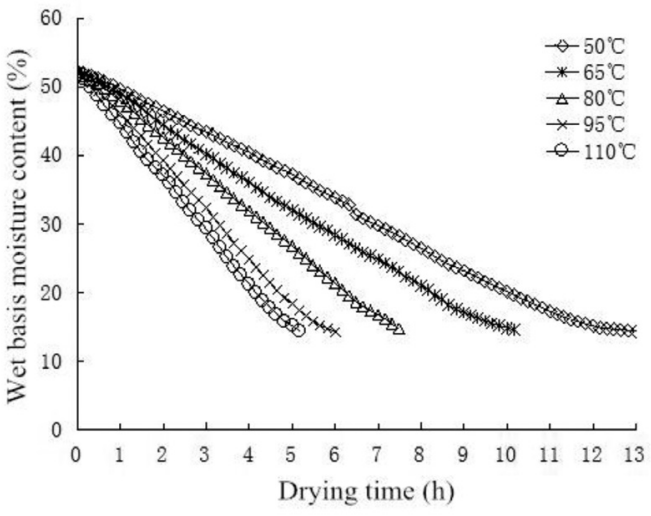

FIGURE 2. Drying curve between moisture rate and time under $3.6 \mathrm{~m} / \mathrm{s}$

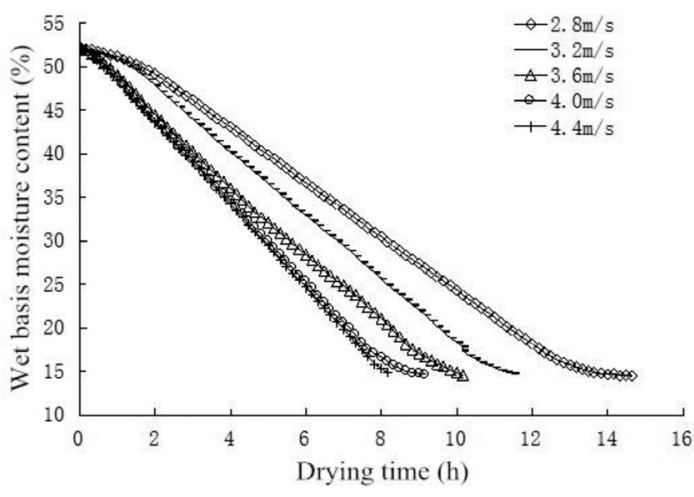

FIGURE 3. Drying curve between moisture rate and time under $65^{\circ} \mathrm{C}$

\section{INFLUENCE OF MEDIUM WIND SPEED AND TEMPERATURE ON DRYING RATE}

Figure 4 shows that for each drying temperature, the drying rate curve involved preheating drying stage, constant-speed drying stage, and decelerated drying stage. The first stage was the initial stage of drying; that was, the preheating stage. In this stage, the temperature of the material rose rapidly, and the drying rate increased from zero to the maximum value. At this stage, the moisture content of the material is high. In addition, the internal moisture diffusion rate was higher than the external evaporation rate. Moreover, the internal moisture of the material continuously shifted to the surface that played a leading role in drying material. In the constant-speed drying stage, 
the moisture continued to decrease, and the drying rate was unchanged. At this stage, the rate of moisture (mainly bound water) transferring to the surface was the same as the diffusion rate of surface moisture to the surrounding medium. The heat supplied to the material was all used for evaporation of water, therefore, the drying rate will not substantially change with the moisture content of the material, and the water loss rate reached the maximum. Entering the decelerated drying stage, only the inner deep free water and the colloid-bound water remained. Since the rate of moisture, moving from the inside to the surface of the material cannot keep up with the rate of surface water evaporation. The decline rate of material moisture content was slowed down, and the drying rate was gradually reduced. It can be seen from the analysis of experimental data that the moisture content of materials decreased slowly in the decelerated drying stage, and the drying time was longer than that of other stages, so the energy consumption in this stage was also the largest.

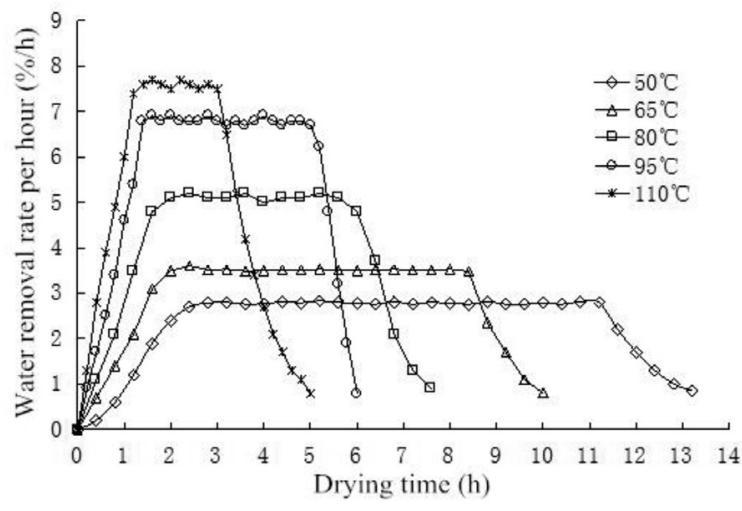

FIGURE 4. Drying rate curve under $3.6 \mathrm{~m} / \mathrm{s}$

On the whole, the higher the temperature of the drying medium, the more severe the rate of changed in the dry preheating stage and decelerated stage, the higher the drying rate in the constant-speed drying stage and the drying time was significantly reduced. However, it can be seen from Figure 4 that the higher the drying medium temperature, the greater the fluctuation of the drying rate in the dry preheating stage and the decelerated step would be, which meant that during the drying process, the drying rate will change remarkably in a short period of time, and the rate at which moisture moved from the inside to the surface of the material cannot keep up with the rate at which the surface moisture evaporates. Therefore, a heatmoisture gradient was formed inside the material, which formed tensile and compressive stress inside the grain, and thus the grain-generated cracks, affecting material quality and yield.

It can be seen from Figure 5 that for each dry wind speed, the drying rate curve also has distinct preheating drying stage, constant-speed drying stage, and decelerated drying stage. During the preheating phase, the material

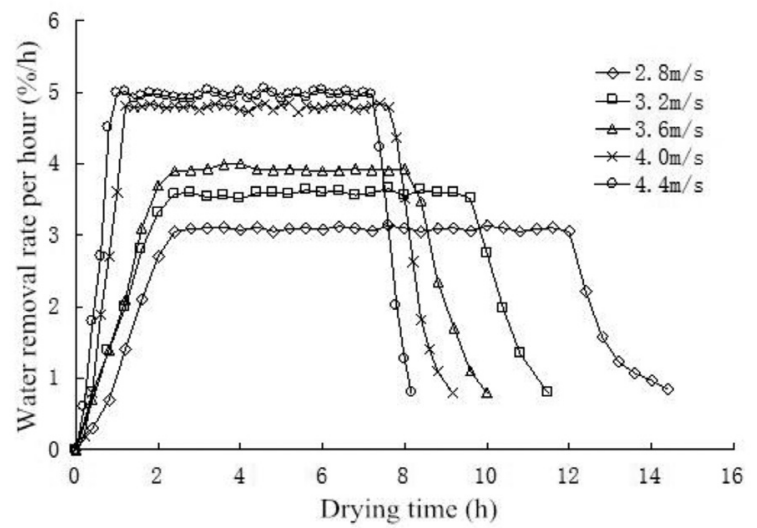

FIGURE 5 . Drying rate curve under temperature $\left(65^{\circ} \mathrm{C}\right)$

temperature rose rapidly, and the drying rate increased from zero to the highest value. At this stage, the higher the media wind speed, the greater the drying rate would be. This was because the moisture on the surface of the material was quickly taken away. In the constant-speed drying stage, the temperature rise was not apparent, and the moisture continued to decrease, and the drying rate was unchanged. During the decelerated drying phase, the drying rate was gradually reduced. It is also known from the experiment that the energy consumption in the decelerated drying stage was the largest.

Overall, the higher the drying wind speed, the greater the drying rate, the higher the drying efficiency, and the shorter the drying time would be. Figure 5 shows that the higher the wind speed of the drying medium, the smaller the influence of the medium wind speed on the drying rate. Therefore, lower wind speed in the drying process would increase the drying rate of materials. With the increase of medium wind speed, the effect on the drying rate became smaller.

\section{INFLUENCE OF MEDIUM WIND SPEED AND TEMPERATURE ON UNIT ENERGY CONSUMPTION}

Figure 6 shows the change rule of unit energy consumption with medium temperature under the condition of wind speed $U=3.6 \mathrm{~m} / \mathrm{s}$ and temperature variation range of $50^{\circ} \mathrm{C} \sim 110^{\circ} \mathrm{C}$. As can be seen from the illustration, the unit energy consumption decreased as the temperature of the medium increased. When the medium temperature was between $50^{\circ} \mathrm{C}$ and $80^{\circ} \mathrm{C}$, the unit energy consumption changed significantly; when the medium temperature was between $80^{\circ} \mathrm{C}$ and $110^{\circ} \mathrm{C}$, the unit heat consumption turned slowly.

It can be seen from the analysis that under the premise of not affecting the quality of the GBR after drying, a higher temperature should be selected, and the drying rate can be increased while reducing the energy consumption. At the same time, considering the change rule of drying rate with medium temperature, the hot air temperature in the early drying stage was selected to be zero levels at $105^{\circ} \mathrm{C}$, the temperature ranged from 90 to $120^{\circ} \mathrm{C}$; and in the late drying 


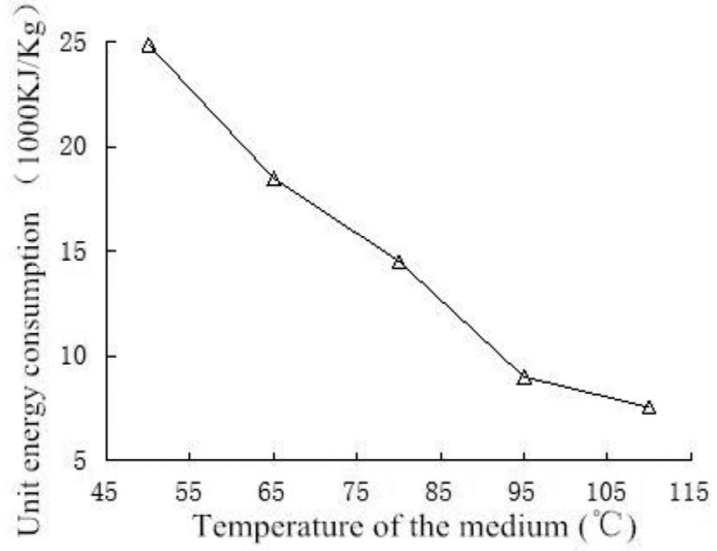

FIGURE 6. Variation of heat consumption per unit

stage, the hot air temperature in the early drying stage was selected to be zero levels at $55^{\circ} \mathrm{C}$, the temperature ranged from 40 to $70^{\circ} \mathrm{C}$ (the specific value range was based on the horizontal value range of the orthogonal design experiment).

\section{ESTABLISHMENT OF THE DRY MATHEMATICAL MODEL}

Data Analysis and Processing The SPSS 16.0 software was used to analyze the experimental data.

Analysis and Selection of Drying Models The fitting degree of the dry model is usually determined by the determination coefficient $\left(R^{2}\right)$, the root mean square error (RMSE), and the chi-square $\left(\chi^{2}\right)$. The larger $R^{2}$ is, the smaller the RMSE sum will be, indicating the better fitting degree.

It can be seen from Table 2 that the $R^{2}$ values of the Page model and the Wang and Singh model under its drying conditions were higher than 0.98 , which was significantly higher than the other three models. And then comparing the RMSE and $\chi^{2}$ under the various dry conditions, the data of Wang and Singh model were between $1.6 \%-2.8 \%$ and $2.5 \times 10^{-4}-5 \times 10^{-4}$, respectively, which was significantly smaller than the other models. Therefore, a comprehensive comparison of the fitting results of the five models showed that the drying process of GBR would be best performed by using the Wang and Singh model.

Fitting of the Dry Model The drying constants a and b in the Wang and Singh model showed a significant linear change with wind temperature and speed, which can be expressed as fellow:

$$
\begin{aligned}
& a=x_{1}+x_{2} T+x_{3} V \\
& b=y_{1}+y_{2} T+y_{3} V
\end{aligned}
$$

where $T$ is the drying temperature, ${ }^{\circ} \mathrm{C} ; V$ is the drying wind speed, $\mathrm{m} / \mathrm{s} ; x_{1}, x_{2}, x_{3}$ are constants; $y_{1}, y_{2}, y_{3}$ are constants.

According to the temperature and wind speed of each experiment and the $\mathrm{a}$ and $\mathrm{b}$ values of the Wang and Singh model, linear regression was performed for (11) and (12), and $x_{1}, x_{2}, x_{3}$ and $y_{1}, y_{2}, y_{3}$ of the Modified Page model were obtained, respectively. The result is as follows:

$$
\begin{aligned}
& a=0.164-0.02 T-0.039 V \\
& b=0.04+0.067 T+0.01 V
\end{aligned}
$$

The Wang and Singh final model can be obtained by bringing the above parameters into the Wang and Singh model equations.

$$
\begin{aligned}
M R= & 1+(0.164-0.02 T-0.039 V) t+ \\
& (-0.004+0.067 T+0.01 V) t^{2}
\end{aligned}
$$

The experimental values of GBR drying at $65^{\circ} \mathrm{C}$ and 3.6 $\mathrm{m} / \mathrm{s}$ wind speed were compared with the predicted values of Wang and Singh final model. As shown in Figure 7, the fitting degree was good, which meant that the model could

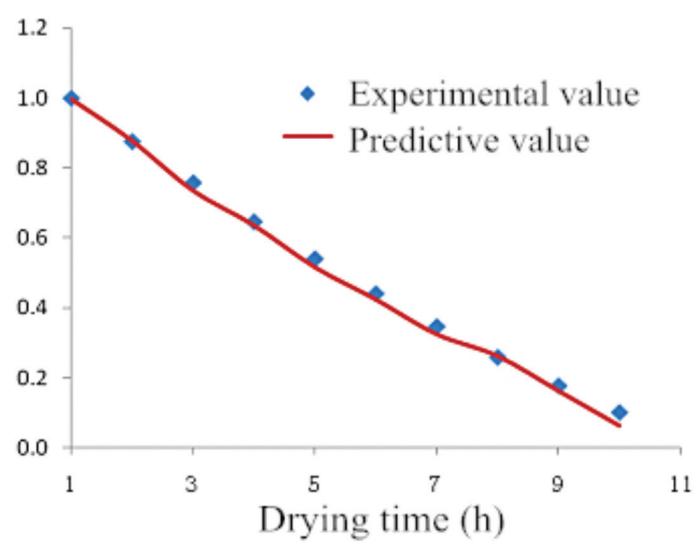

FIGURE 7. Comparison of the predicted values by the Wang and Singh model and experimental values of moisture ratio at $65^{\circ} \mathrm{C}$ and $1.0 \mathrm{~m} / \mathrm{s}$ 
TABLE 2. Statistical analysis of different mathematical models under different drying conditions and relative air velocities

\begin{tabular}{|c|c|c|c|c|c|c|c|c|c|c|}
\hline Models & $\mathrm{T} /{ }^{\circ} \mathrm{C}$ & $\begin{array}{c}\text { air } \\
\text { velocities/ } \\
(\mathrm{m} / \mathrm{s})\end{array}$ & $\mathrm{k}$ & $\mathrm{a}$ & $\mathrm{b}$ & $\mathrm{n}$ & $\mathrm{g}$ & $\mathrm{R} 2$ & RMSE/\% & $\chi^{2}$ \\
\hline \multirow{10}{*}{ Newton } & 50 & 3.6 & 0.133 & & & & & 0.932 & 8.29 & $6.88 \times 10^{-3}$ \\
\hline & 65 & 3.6 & 0.167 & & & & & 0.939 & 8.02 & $6.44 \times 10-3$ \\
\hline & 80 & 3.6 & 0.207 & & & & & 0.932 & 8.52 & $7.25 \times 10-3$ \\
\hline & 95 & 3.6 & 0.304 & & & & & 0.921 & 10.46 & $10.95 \times 10-3$ \\
\hline & 110 & 3.6 & 0.337 & & & & & 0.924 & 10.321 & $10.65 \times 10-3$ \\
\hline & 65 & 2.8 & 0.120 & & & & & 0.930 & 8.36 & $6.99 \times 10-3$ \\
\hline & 65 & 3.2 & 0.146 & & & & & 0.922 & 9.2 & $8.47 \times 10-3$ \\
\hline & 65 & 3.6 & 0.190 & & & & & 0.939 & 8.45 & $7.14 \times 10^{-3}$ \\
\hline & 65 & 4 & 0.210 & & & & & 0.922 & 10.07 & $10.14 \times 10^{-3}$ \\
\hline & 65 & 4.4 & 0.205 & & & & & 0.921 & 9.7 & $9.41 \times 10^{-3}$ \\
\hline \multirow{10}{*}{ Page } & 50 & 3.6 & 0.4 & & & 1.625 & & 0.991 & 9.47 & $8.86 \times 10^{-3}$ \\
\hline & 65 & 3.6 & 0.61 & & & 1.575 & & 0.984 & 9.36 & $8.47 \times 10^{-3}$ \\
\hline & 80 & 3.6 & 0.83 & & & 1.526 & & 0.981 & 9.08 & $8.11 \times 10^{-3}$ \\
\hline & 95 & 3.6 & 0.74 & & & 1.582 & & 0.979 & 8.45 & $7.58 \times 10^{-3}$ \\
\hline & 110 & 3.6 & 0.77 & & & 1.627 & & 0.983 & 8.72 & $7.81 \times 10^{-3}$ \\
\hline & 65 & 2.8 & 0.34 & & & 1.626 & & 0.993 & 9.32 & $8.68 \times 10^{-3}$ \\
\hline & 65 & 3.2 & 0.44 & & & 1.648 & & 0.986 & 9.35 & $8.74 \times 10^{-3}$ \\
\hline & 65 & 3.6 & 0.79 & & & 1.521 & & 0.986 & 9.12 & $8.31 \times 10^{-3}$ \\
\hline & 65 & 4 & 0.71 & & & 1.648 & & 0.981 & 8.58 & $7.37 \times 10^{-3}$ \\
\hline & 65 & 4.4 & 0.76 & & & 1.634 & & 0.978 & 8.69 & $7.56 \times 10^{-3}$ \\
\hline \multirow{10}{*}{$\begin{array}{l}\text { Henderson } \\
\text { and Pabis }\end{array}$} & 50 & 3.6 & 0.163 & 1.193 & & & & 0.956 & 5.08 & $2.58 \times 10^{-3}$ \\
\hline & 65 & 3.6 & 0.203 & 1.209 & & & & 0.951 & 3.71 & $1.37 \times 10^{-3}$ \\
\hline & 80 & 3.6 & 0.253 & 1.248 & & & & 0.955 & 5.33 & $2.85 \times 10^{-3}$ \\
\hline & 95 & 3.6 & 0.409 & 1.376 & & & & 0.938 & 6.73 & $4.53 \times 10^{-3}$ \\
\hline & 110 & 3.6 & 0.409 & 1.192 & & & & 0.934 & 6.05 & $3.66 \times 10^{-3}$ \\
\hline & 65 & 2.8 & 0.149 & 1.201 & & & & 0.960 & 4.26 & $1.82 \times 10^{-3}$ \\
\hline & 65 & 3.2 & 0.184 & 1.23 & & & & 0.953 & 3.78 & $1.47 \times 10^{-3}$ \\
\hline & 65 & 3.6 & 0.242 & 1.263 & & & & 0.971 & 3.25 & $1.06 \times 10^{-3}$ \\
\hline & 65 & 4 & 0.276 & 1.325 & & & & 0.993 & 4.11 & $1.69 \times 10^{-3}$ \\
\hline & 65 & 4.4 & 0.274 & 1.312 & & & & 0.985 & 4.95 & $2.45 \times 10^{-3}$ \\
\hline \multirow{10}{*}{ Two term } & 50 & 3.6 & 0.163 & 0.948 & 0.245 & & 0.163 & 0.956 & 5.08 & $2.58 \times 10^{-3}$ \\
\hline & 65 & 3.6 & 0.206 & 0.604 & 0.605 & & 0.206 & 0.962 & 4.34 & $1.88 \times 10^{-3}$ \\
\hline & 80 & 3.6 & 0.253 & 0.739 & 0.509 & & 0.253 & 0.955 & 5.33 & $2.85 \times 10^{-3}$ \\
\hline & 95 & 3.6 & 0.409 & 0.126 & 1.25 & & 0.409 & 0.938 & 6.84 & $4.68 \times 10^{-3}$ \\
\hline & 110 & 3.6 & 0.409 & 0.596 & 0.596 & & 0.409 & 0.931 & 7.09 & $5.04 \times 10^{-3}$ \\
\hline & 65 & 2.8 & 0.149 & 0.615 & 0.586 & & 0.149 & 0.96 & 4.42 & $1.95 \times 10^{-3}$ \\
\hline & 65 & 3.2 & 0.184 & 0.638 & 0.592 & & 0.184 & 0.953 & 4.18 & $1.75 \times 10^{-3}$ \\
\hline & 65 & 3.6 & 0.242 & 0.635 & 0.629 & & 0.242 & 0.971 & 3.24 & $1.05 \times 10^{-3}$ \\
\hline & 65 & 4 & 0.281 & 1.332 & 0 & & -4.206 & 0.964 & 5.58 & $3.12 \times 10^{-3}$ \\
\hline & 65 & 4.4 & 0.274 & 0.67 & 0.641 & & 0.274 & 0.967 & 4.95 & $2.45 \times 10^{-3}$ \\
\hline \multirow{10}{*}{$\begin{array}{l}\text { Wang and } \\
\text { Singh }\end{array}$} & 50 & 3.6 & & -0.085 & 0 & & & 0.994 & 2.47 & $6.12 \times 10^{-4}$ \\
\hline & 65 & 3.6 & & -0.108 & 0.001 & & & 0.973 & 1.67 & $2.79 \times 10^{-4}$ \\
\hline & 80 & 3.6 & & -0.11 & 0.003 & & & 0.983 & 1.72 & $2.98 \times 10^{-4}$ \\
\hline & 95 & 3.6 & & -0.184 & 0.002 & & & 0.990 & 2.77 & $7.65 \times 10^{-4}$ \\
\hline & 110 & 3.6 & & -0.205 & 0.001 & & & 0.995 & 1.95 & $3.82 \times 10^{-4}$ \\
\hline & 65 & 2.8 & & -0.075 & 0 & & & 0.995 & 2.12 & $4.51 \times 10^{-4}$ \\
\hline & 65 & 3.2 & & -0.088 & 0 & & & 0.995 & 2.16 & $4.68 \times 10^{-4}$ \\
\hline & 65 & 3.6 & & -0.127 & 0.003 & & & 0.989 & 1.81 & $3.26 \times 10^{-4}$ \\
\hline & 65 & 4.0 & & -0.136 & 0.002 & & & 0.991 & 1.94 & $3.78 \times 10^{-4}$ \\
\hline & 65 & 4.4 & & -0.129 & 0.001 & & & 0.993 & 2.03 & $4.12 \times 10^{-4}$ \\
\hline
\end{tabular}


predict the moisture ratio of GBR at any time, temperature, and wind speed in the range of drying experiment.

\section{CONCLUSION}

This innovative device could obtain timely and accurate experimental data and observe the weight change rule of materials at each moment, thus ensuring the reliability of data. In order to provide the basis for optimizing the drying process and guiding the design of GBR dryer, and to lay a foundation for the further experiment of GBR drying technology, the change rule of drying rate and unit energy consumption with a single factor under a specific wind temperature and speed was discussed in this paper. The drying characteristics of GBR were as follows: As the temperature and wind speed rose, the drying rate increased correspondingly. However, when the temperature exceeds $95^{\circ} \mathrm{C}$, and the wind speed reached $3.6 \mathrm{~m} / \mathrm{s}$ or more, the change of drying rate did not change significantly. The unit energy consumption decreased with the increase of medium temperature and increased with the increase of medium wind speed. Wang and Singh's model could best simulate the drying process of GBR. Under the experimental conditions, the predicted value of Wang and Singh's model fitted well with the experimental value, meanwhile, by determining the functional expressions of the model's relevant parameters with temperature and wind speed, the change of water ratio of GBR at any time could be accurately predicted.

\section{ACKNOWLEDGEMENTS}

The authors wish to acknowledge the financial support from Nanjing Agricultural University. There is no external funding for this research.

\section{REFERENCES}

Argo, B.D., Sandra, S. \& Ubaidillah, U. 2018. Mathematical modeling on the thin layer drying kinetics of cassava chips in a multipurpose convective-type tray dryer heated by a gas burner. Journal of Mechanical Science and Technology 32(7): 3427-3435.

Aykin-Dincer, E. \& Erbas, M. 2018. Drying kinetics, adsorption isotherms and quality characteristics of vacuum-dried beef slices with different salt contents. Meat Sci. 145: 114-120.

Bordiga, M., Gomez-Alonso, S., Locatelli, M., Travaglia, F., Coïsson, J.D., Hermosin-Gutierrez, I. \& Arlorio, M. 2014. Phenolics characterization and antioxidant activity of six different pigmented Oryza sativa L. cultivars grown in Piedmont (Italy). Food Res. Int . 65: 282-290.

Cáceres, P.J., Peñas, E., Martinez-Villaluenga, C., Amigo, L. \& Frias, J. 2017. Enhancement of biologically active compounds in germinated brown rice and the effect of sun-drying. $J$. Cereal Sci. 73: 1-9.

Caceres, P.J., Martinez-Villaluenga, C., Amigo, L. \& Frias, J. 2014. Assessment on proximate composition, dietary fiber, phytic acid and protein hydrolysis of germinated Ecuatorian brown rice. Plant Foods Hum. Nutr. 69(3): 261-267.
Canabarro, N.I., Mazutti, M.A. \& Carmo Ferreira, M. 2019. Drying of olive (Olea europaea L.) leaves on a conveyor belt for supercritical extraction of bioactive compounds: Mathematical modeling of drying/extraction operations and analysis of extracts. Industrial Crops and Products 136: 140-151.

Chandra Mohan, V.P. \& Talukdar, P. 2010. Three dimensional numerical modeling of simultaneous heat and moisture transfer in a moist object subjected to convective drying. International Journal of Heat and Mass Transfer 53(21): 4638-4650.

Chungcharoen Hatchapol, Prachayawarakorn Somkiat, Tungtrakul Patcharee \& Soponronnarit Somchart. 2014. Effects of germination process and drying temperature on gamma-aminobutyric acid (GABA) and starch digestibility of germinated brown rice. Dry. Technol. 32(6): 742-753.

El Khadraoui, A., Hamdi, I., Kooli, S. \& Guizani, A. 2019. Drying of red pepper slices in a solar greenhouse dryer and under open sun: Experimental and mathematical investigations. Innov. Food Sci. Emerg. Technol. 52: 262-270.

Hao, C.L., Lin, H.L., Ke, L.Y., Yen, H.W. \& Shen, K.P. 2019. Pre-germinated brown rice extract ameliorates high-fat diet-induced metabolic syndrome. J. Food Biochem. 43(3): e12769.

Idlimam, A., Lamharrar, A., Bougayr, E.H., Kouhila, M. \& Lakhal, E.K. 2016. Solar convective drying in thin layers and modeling of municipal waste at three temperatures. Appl. Therm. Eng. 108(9): 41-47.

Jian, F. \& Jayas, D.S. 2018. Characterization of isotherms and thin-layer drying of red kidney beans, Part I: Choosing appropriate empirical and semitheoretical models. Dry. Technol.36(14): 1696-1706.

Lakshmi, D.V.N., Muthukumar, P., Layek, A. \& Nayak, P.K. 2018. Drying kinetics and quality analysis of black turmeric (Curcuma caesia) drying in a mixed mode forced convection solar dryer integrated with thermal energy storage. Renew. Energy 120: 23-34.

Lee, J.H. \& Zuo, L. 2013. Mathematical modeling on vacuum drying of Zizyphus jujuba Miller slices. J. Food Sci. Technol. 50(1): 115-121.

Lee, Y.T., Shim, M.J., Goh, H.K., Mok, C. \& Puligundla, P. 2019. Effect of jet milling on the physicochemical properties, pasting properties, and in vitro starch digestibility of germinated brown rice flour. Food Chem. 282: 164-168.

Leite, L.d.S., Matsumoto, T. \& Albertin, L.L. 2018. Mathematical modeling of thermal drying of facultative pond sludge. $J$. Environ. Eng. 144(9): 04018079.

Li, K., Hu, G., Yu, S., Tang, Q. \& Liu, J. 2018. Effect of the iron biofortification on enzymes activities and antioxidant properties in germinated brown rice. J.Food Meas. Charact. 12(2): 789-799.

Li, Y., Su, X., Shi, F., Wang, L. \& Chen, Z. 2017. Hightemperature air-fluidization-induced changes in the starch texture, rheological properties, and digestibility of germinated brown rice. Starch - Stärke 69(9-10): 1600328.

Liu, K., Zhao, S., Li, Y. \& Chen, F. 2018. Analysis of volatiles in brown rice, germinated brown rice, and selenised germinated brown rice during storage at different vacuum levels. J. Sci. Food. Agric. 98(6): 2295-2301.

Liu, X.C., Qin, N. \& Luo, Y.K. 2016. Application of a combination model based on an error-correcting technique 
to predict quality changes of vacuum-packed bighead carp (Aristichthys nobilis) fillets. LWT-Food Sci. Technol. 74: 514-520.

Mujaffar, S. \& Sankat, C.K. 2015. Modeling the drying behavior of unsalted and salted catfish (Arius sp.) Slabs. J. Food Process. Preserv. 39(6): 1385-1398.

Ranmeechai, N. \& Photchanachai, S. 2017. Effect of modified atmosphere packaging on the quality of germinated parboiled brown rice. Food Sci. Biotechnol. 26(2): 303-310.

Sahin, U.\& Ozturk, H.K. 2016. Effects of pulsed vacuum osmotic dehydration (PVOD) on drying kinetics of figs (Ficus carica L). Innov. Food Sci. Emerg. Technol. 36: 104-111.

Shen, L., Zhu, Y., Wang, L., Liu, C., Liu, C. \& Zheng, X. 2019 Improvement of cooking quality of germinated brown rice attributed to the fissures caused by microwave drying. J.Food Sci. Technol. 56: 2737-2749.

Vijayan, S., Arjunan, T.V. \& Kumar, A. 2016. Mathematical modeling and performance analysis of thin layer drying of bitter gourd in sensible storage based indirect solar dryer. Innovative Food Science and Emerging Technologies 36: 59-67.

Yodpitak Sittidet, Sugunya Mahatheeranont, Dheerawan Boonyawan, Phumon Sookwong, Sittiruk Roytrakul \& Orranuch Norkaew. 2019. Cold plasma treatment to improve germination and enhance the bioactive phytochemical content of germinated brown rice. Food Chemistry 289: 328-339.
Yousaf, K., Abbas, A., Zhang, X., Soomro, S.A., Ameen, M. \& Chen, K. 2018. Effect of multi-stage drying on energy consumption, the rate of drying, rice quality and its optimization during parboiling process. Fresenius Environmental Bulletin 27: 8270-8279.

Department of Agricultural Engineering

College of Engineering

Nanjing Agricultural University

Nanjing, Jiangsu 210031

P.R. China

*Corresponding author; email: kunjiechen@njau.edu.cn

Received: 3 June 2019

Accepted: 21 August 2019 